\title{
Diversity and Gender Parity in Nigeria: A Situation Analysis
}

\author{
Fapohunda, Tinuke $M$. \\ Department of Industrial Relations and Personnel Management \\ Lagos State University Ojo, Nigeria \\ Email: tkfap@yahoo.com
}

\section{Doi:10.5901/ajis.2016.v5n3s1p254}

\begin{abstract}
Diversity as a subject has received increased interest in modern times and all and sundry appears to be speaking about it, there doesn't appear to be much actual progress. Contemporary studies confirm that more novel problem-solving and superior decision-making arises when diverse views and perceptions are incorporated in a shared pool of knowledge. Consequently, ineffectiveness in diversifying work teams especially with respect to gender portends the risk of losing the war on talent. Nigeria's population of about some 170.5 million people constitutes the largest population of any African country. Of the vast population, females constitute 49\%; about 82.2 million females. Consequently, all discourses on Nigeria's prospect should inevitably involve contemplation of females, their position and those obstacles they face in making the future. Generating a gender sensitive nation obliges deliberate, continuous effort. To sustain inclusion initiatives, gender diversity must be embedded into the fabric of the country. Progressive management is now more than a "one size fits all" approach; it demands a grasp and endorsement of the characteristic values and point of views individuals bring to the table. Women and men bring diverse, but homogeneously vital benefits to the national development. Subsequently, discerning leaders must promote their consciousness of the disparities and build an atmosphere where both are embraced and respected. Gender stereotyping is so entrenched in the Nigerian culture, it is frequently imperceptible. Discrimination commonly happens arising from ignorance rather than premeditated or malicious intent but knowledge obliterates ignorance and reduces stereotyping. Undoubtedly women are Nigeria's unseen resource and advancing their cause increases productivity, encourage sustainable growth, peace and improved health. This study presents a situation analysis and examines the significant issues that require tackling in order to exploit the prospects of females. It emphasises the serious issues and depicts the seriousness and importance of the situation. It therefore calls attention to analysed behaviours and with a new awareness of gender differences with the aim of educating stakeholders, and training individual team members for inclusion and excellence.
\end{abstract}

Keywords: Diversity, Gender, Parity, Situation, Analysis

\section{Introduction}

Diversity involves dissimilarities or variations between individuals arising from ethnicity, age, race, belief, sexual alignment, socio-economic grouping, gender, and abilities/incapacities. It elevates important ethical concerns and social representative issue as well. Current competitive global milieu presents many significant tests to build competitive advantage by boosting competence, excellence, originality and sensitivity added to the management of a diverse citizenry. Diversity is crucial to exploit the talents of individual from varied backgrounds, because as Makower, Thomas and Schuler (1995) affirm, their dissimilarities deepen, expand and provide the competitive edge. Consequently, countries aiming for improved national development and the competitive edge must engage a variety of people and exploit them. Interestingly though while there has been talk about it, not much seems to be seen in terms of making legitimate progress by effectively ensuring gender balance in Nigeria irrespective of the fact that the last two decades at least, has witnessed various contributions in gender diversity seminars.

Contemporary studies like Ugwulebo (2011) and Halkias, et al. (2011) validate that more innovative problemsolving and superior decision-making occurs when diverse views and perceptions are included in a shared pool of knowledge. Consequently, countries that fail to diversify their leadership teams especially with respect to gender stand the risk of losing the war on talents. Generating a gender diverse national management team necessitates intentional, ongoing effort. To maintain inclusion ideas, diversity must be embedded into the fabric of a nation.

Progressive national leadership management is now beyond a "one size fits all" approach; it entails a comprehension and approval of the distinctive merits and outlooks individuals bring to the communal table. Women and men bring diverse, but uniformly important assets to the nation. Consequently, developing countries like Nigeria must elevate their consciousness of the disparities and build an atmosphere where both genders are embraced and respected. 
Gender stereotyping is so entrenched in the Nigerian culture, it is frequently imperceptible. Discrimination commonly happens arising from ignorance rather than premeditated or malicious intent but knowledge obliterates ignorance and reduces stereotyping. This paper gives a situation analysis of gender parity in Nigeria and examines the significant issues that require tackling in order to exploit the prospects of females. It concentrates consideration on the dire issues and depicts the seriousness and importance of the situation. It therefore calls attention to analysed behaviours with a new awareness of gender differences with the aim of educating stakeholders, and training individual team members for inclusion and excellence.

\section{Literature}

\subsection{Diversity}

Cox, O'Neill and Quinn (2001) sees diversity as the differences in social and cultural identities amongst people existing together in a defined system. Loden and Rosener (2009) perceives it as the mass individual dissimilarities and similarities that exist between people. Mckenna (2009) denotes it as discriminatory and non-inclusive behaviours with psychological foundations. Corbridge and Pilbeam (2010) delineates it as dealing with a person or group of people with a reduced consideration because of incapacity, race, religious conviction, age, sex or sexual alignment or by applying certain conditions or requirements that are more easily satisfied by one group than another. The International Labour Organization (ILO) (2006) distinguishes diversity as the demographic differences in the workforce of an organization or nation. Human beings come in assorted shapes, sizes, opinions and colours and this assortment symbolizes the core of diversity. Diversity necessitates nations assuming novel ways of managing and valuing it. Instead of pitting groups against each other, leaders must endeavour to identify the distinctive differences and contributions of each individual and group to national goals and objectives.

\subsection{Gender Parity in Nigeria}

Nigeria demonstrates extraordinary and disturbing depths of disparity. The British Council Nigeria (2012) reports that Nigeria is today catalogued as a lower middle-income nation. A major challenge currently facing the country involves creating viable employment generating development and reinforcing establishments, to support culpability and facilitate fair sharing of the profits of that development. The report adds that except inequity is addressed urgently, it possesses the prospect of breeding and aggravating disputes. British Council Nigeria also alludes to Filma (2008) which avows an association among gender inequity, additional systems of unfairness and clashes in the particular environment of the political economy of Nigeria. Furthermore, Caprioli (2005) and Melander (2005) and Iheduru (2006) all distinguish a link between gender egalitarianism and intense intrastate wars. This relationship underscores the significance of appreciating and tackling gender relations.

\subsection{Components of Gender Gaps in Nigeria}

According to the Gender in Nigeria Report (2013), the inability of majority of Nigerian women to add extra to family monetary earnings reduces their capacity to impact expending at domestic level and limits their capability to add to financial development. Hardly any rural or metropolitan women possess land, consequently finding it tougher to advance monetary assets. Moreover, women are less in formal sector employment, but are rather refined in the microenterprise segment.

Both in the terms of inputs they make to development and the advantages they receive from it, females in Nigeria remain the underclass and are deficient in equivalence of prospect. While education, class, ethnicity, kinship, marital status and religion frequently alleviate or complicate the result, the story is correct of all women in Nigeria. Nolte et al. (2010) contends that since 1999 and the political open-mindedness which permitted a superior grade of liberty of worship, the religious element has gained additional importance. An imperative element of the fight for gender parity as The British Council Nigeria (2012) quoting Edozie (2007) asserts is the environmental dissection between the North, with mostly Muslims, as against the South, with primarily but not wholly Christians.

Added to the North- South segregation (since the people in the industrial South are inclined to manifest better conditions than the ones living in the North) is the rural-urban segregation in all parts of the country. Reminiscent of most of Africa, urban areas tend to be characterized by improved quality of life arising partly from insufficient investment in 
rural infrastructure and services; besides state capitals both in the North and the South seem to exhibit improved conditions compared to the smaller cities in their provinces.

\subsubsection{Gender Disparities in Education}

Nigeria is characterized by gender inequality in registration equally in the primary and secondary levels of education and this according to Dauda (2007) hinders it from garnering its demographic dividend. Primary school registration numbers have wavered a bit in the recent past. Dauda affirms that once the numbers achieved a pinnacle in 2010, they have since continued to be somewhat stagnant. UNESCO (2014) puts the current net attendance ratio at $61 \%$. This is troubling since it still falls short of the EFA goal of putting all children of school age in school.

The British Council Nigeria (2013) also observes that Theobald et al., (2012) posits that Nigeria still has additional youngsters of primary school age who are unfortunately not in school compared to any other nation in the globe. Again the 2015 Nigeria Education Data Survey indicates that about 1.8 million kids ( $8.1 \%$ of kids aged $6-14$ ) were out of school during the period of the study. Of this, almost $61 \%$ were girls. While the gender gap seems to be closing, the total registration proportion of girls remains ominously poorer when compared to that of boys. Also, girls' finishing rates are usually lower than that of boys. UNESCO (2014) indicates that in some Northern States, confirmed girls' finishing rates are as low as 7.8\%. Mahdi (2011) asserts that a common causative social factor is that some parents have a predilection for their male children to attend school since daughters neither take over nor continue the family name. Hunt (2008) attributes the very low finishing rates to a permutation of factors like: parental condemnation of the secular curriculum; user costs; bullying and early marriage. Again, most girls who finish primary school do not proceed to secondary school. UNESCO (2015) puts the net enrolment rate for girls in the North at 22\%. The British Council Nigeria (2012) Gender Equality Report avows that over $80 \%$ of females in eight of the Northern States are incapable of reading (compared with $54 \%$ for men). It also suggests for instance that in Jigawa State, $94 \%$ of women (42\% of men) are not literate. The continued comparatively poor enrolment and elevated dropout rates is disheartening bearing in mind the significance of education for Nigeria's future.

\subsubsection{Gender Disparities in Political Participation}

Virtually all segments of human development are characterized by an absence of gender equality. Despite the fact that women form approximately one half of the Nigerian populace, their involvement in democratic structures and procedures remain insignificant as a result of gender inequalities in the political arena. Governance has always been about power. It is the power or personality to dominate a group. Males have been in control of power and leadership in the world and rooted labels about females have barred females from occupying their lawful positions as equivalent companions. Nation building requires the effective and efficient mobilization of available human (irrespective of gender) and material resources. The male gender controls government thus holding the reins of power relations and exerting sole authority over resource allocation and control.

Melander (2005) contends that worldwide practice campaigns that better female governmental involvement is related to reduced degrees of intrastate and local wars and violence. The United Nations Economic Commission for Africa (UNECA) (2002) states that "....... If all people were allowed to share the opportunities available, development will be achieved at the most rapid rate possible. Women constitute the mass of persons on the electoral rolls during voting, exhibit considerable attendance at political campaigns, and meetings as enthusiasts and performers, but they are seldom duly registered members of political parties and they hold minority party posts or political positions. in Nigeria, women's involvement in politics are limited by quite a few dynamics including: discriminatory socio-cultural practices; economic or financial factors: the violent nature of Nigerian politics; the part of socialization in the relegation of females; lack of educational opportunities which also constitutes a major hindrance to effective political participation by females. Badmus (2015) attests to the fact that in Nigeria's 2015 General Elections, among the 52 million qualified enumerated voters, females made up about 32 million nonetheless only a mere $2.34 \%$ of them won elections. Women membership of political parties as shown in party registers in 2015 was $5 \%$, party executives who were female was $7 \%$ while females who made it to party representatives were $8 \%$. In this current and $8^{\text {th }}$ National Assembly, there are only 7 females out of 109 Senators, 12 females out of the 360 House of Representative Members, 18 females out of the 990 State House of Assembly members, 143 females out of the 8810 Local government Councillors, and 11 females out of the 774 Local Government Chairmen. A similarly low drift is continual in appointive posts. Just 5 females were among the ministers and presidential advice-givers signed up in 2015; and of the 52 ambassadors merely 4 females made the list. The federal 
government again engaged 750 people in 137 federal boards just 68 of whom were females. Only 11.3 per cent of cabinet members are women, there is only one elected female governor, 1.1 per cent women councillors, 1.2 per cent local government chairperson, 2.8 per cent senators and 3.3 per cent representation at the House of Representatives. While some modest improvement has been recorded, the percentage of women representation is far below the anticipated 30\% representation of the Affirmation Action principles and the principles contained in the national policy for women. Okpara (2004) contends that a quick investigation of the pattern of women who contest elections expose that the greatest numbers of these women, either by objects of biological or marital indices enjoy dominant political connections with influential politicians. While some level of progress has been achieved so far in improving the social, cultural and material well-being of women, not much has been achieved in the area of political leadership. Consequently, politics is still a male dominated area and very few women have ventured to play active roles in politics.

\subsubsection{Gender Disparities in Employment}

The recent economic downturn in Nigeria added to the abyss between employment generation and the progression in the volume of job hunters have combined to aggravate the unemployment condition both for women and men. Nevertheless, a 2012 study by this author found that women countenance superior susceptibilities in the job market owing to factors like their comparative inadequacies in schooling and training, the inclination to guide females into particular occupations, the incessant substantial encumbrances arising from free domestic labour, having children and caring for the children, all of which limit the period and vigour left for pay-earning activities.

UNDP (2014) posits that females have about $67 \%$ fewer chances compared to males of getting wage occupations and only about $30 \%$ of 10 females in Nigeria's labour force are paid employees. Fapohunda (2012) notes that between 1970 and 2009; the formal sector involvement rates for females fell from 57 per cent to 53 per cent. 2.5 million females were retrenched from their jobs between 1985 and 2000 as upshots of the Structural Adjustment Programme. Although they were only 6 per cent of formal sector workers cut back, women accounted for 31 per cent of the cut back workers. Women had controlled the poorer strata of the social services sector, which encountered the fullest budget censors. Many of such retrenched women relocated to the informal sector. Fapohunda indicates that the non-agrarian informal segment today engages up to 25 per cent of the female workforce, customarily in petty trading and home-centred processing and manufacturing, which are characterised by poor access to approved means of credit or data. Moreover, these female employees never enjoy the gains of minimum pay and social security endowments and are obliged to cater for their own health and superannuation needs. Consequent on the decline of formal sector employments, the informal sector has developed into a "safe haven" for women due to its small capital requirements and simplicity of admission. For most females, involvement in the informal sector constitutes a subsistence tactic, even if they still encounter firm opposition from fresh players, including males who are unable to get formal sector work.

Overall, though, women's poor access to inexpensive credit, materials, technical assistance and facilities inhibits them from growing their businesses. The informal area where females prevail is typified by little efficiency and camouflaged joblessness. The British Council Nigeria (2013) acknowledges that in Africa, Nigeria possesses one of the bottom ratios of female private enterprise because the greatest numbers of females are focused in unplanned, littleexperience, small waged informal sector work. Moreover UNDP (2014) notes that only a mere $7.2 \%$ of females are owners of the properties they cultivate, a situation which reduces their ability to obtain credit and limits free enterprise and commercial actions.

\subsubsection{Gender Disparities in Earnings}

Gender wage disparities involve the comparative variances in the normal gross incomes of males and females in an economy. There is agreement that there are gender wage dissimilarities contrary to females and supportive of males. Equal pay law was announced in the Nigeria over four decades ago. Gender parity law was additionally strengthened by the 2007 Gender Equality Duty relating to all public bodies and aspects of the 2010 Equality Act. However, UNDP (2012) specifies that Nigeria's gender wage gap constitutes one of the topmost globally and females are undersold in the belter paid, more commanding places. Significant rural-urban differences in income distribution impact particularly on women, because as the British Council Nigeria Gender Impact Report (2014) indicates, 54 million out of Nigeria's 80.2 million females dwell in and are employed in the countryside regions, where they offer $60-79 \%$ of the country workforce. World Bank (2009) submits that an assortment of impediments, such as procreative responsibilities, meagre access to creative assets, and difficulties concomitant with poor levels of education, collectively explain the observed gender disparities in 
income. Besides, a gender prejudice in allocation of income tax payments implies that female taxpayers are burdened unreasonably. The substantial pay inequity between males and females in Nigeria reveals their unequal chances to make a living. The report again affirms that as Okpara (2004) opines, additional pay discrepancies can be attributed to workplace gender discrimination in both the private and public segments. The British Council Nigeria Gender Impact Report (2014) quotes Oyelere (2007) as indicating that in 2007 males got on average about N2, 300 monthly more than females and the earnings gap increased at least US\$23 monthly at this time. This comparison of the earnings of males and females with similar levels of education indicates that, females at all scholastic levels make less than their male colleagues and sometimes males with less education receive higher pays than more educated female colleagues. A conduit to female empowerment is training and employment. In Nigeria, it is obviously somewhat complex to improve earnings simply through scholastic criterions; structural barricades must move prior to education making a change for women. Morrison et al. (2007) emphasizes the price of inequity and contend that it is excellent economics to guarantee income uniformity amongst males and females.

\subsubsection{Gender Disparities in Poverty}

The British Council Nigeria (2013) affirms that irrespective of the substantial affluence and resources in the country, 54\% of the inhabitants of Nigeria live in poverty. In Nigeria, the woman is employed in agriculture, informal income generating activities, health and education, all tasks essential to society's continued existence but many of them live in poverty. Fapohunda (2013) affirms that poverty takes a female face the female's particular poverty is a great deal more encompassing than the poverty of the male and this not only intimidates nationwide subsistence and well-being but constitutes is a challenge to sustainable development. The UNDP (2013) indicates that $70 \%$ of persons in poverty are females and adds that for Nigeria, returning to democratic rule in 1999 improved the country's chances for development. Nonetheless remarkable progress has not occasioned employments besides a great deal of the prosperity engendered is controlled by a small number of persons with about $50 \%$ of the population grasping at just $10 \%$ of total national income. UNDP (2012) notes that between 1998 and 2011, inequity in Nigeria aggravated from 0.43 to 0.49 . The nation was thus positioned in the midst of those with the utmost inequity levels globally. The poverty challenge in the nation is somewhat an element of extraordinary disparity that is evident in very disparate pay dispersal and discrepancies in access to rudimentary structure, training, teaching and employment prospects. Bearing in mind, the now recognized connection between female earnings and household results, the examination of gendered poverty brings up a probe into the number of children that can conceivably be elevated out of lack and indigence with the realization of gender equality. Obviously the price of gender inequity in Nigeria is significantly greater than frequently supposed.

\section{Efforts at Achieving Gender Parity}

The search for women recognition has always been misconstrued and misinterpreted to imply physical or biological equality but the contemporary thinking is not about that kind of equality but the equality of recognition given to every individual human-being as equal before God, the law, and human beings. Equal value must be attached to every individual's contribution in society not considering their sexes.

The convention for the Elimination of every type of Discrimination against Women (CEDAW) was approved over thirty years ago by the United Nations General Assembly, and Nigeria was one of the countries that ratified it. The Convention obliges member nations to follow a regulation of removing by all means discrimination against women through very suitable methods and devoid of deferment, to re-affirm the parity of constitutional rights for females in the community and the household, take the plunge against societal foundations of female inequity and to eradicate laws, labels, traditional practice and preconceptions that harm women's wellbeing.

Again, the Nigerian Constitution assures females' parity with males. Section 17 (1) of the Constitution affirms that 'the Federal Republic of Nigeria will be founded on the values of independence, egalitarianism and social fairness'. Nigerian citizens will not to be bestowed any privilege or benefit that is not conferred to other nationals of Nigeria of other national groups and, interalia, gender. As Olojede (2009) points out the motivating standard presumable from the Nigerian legitimate provisions is that of equal opportunity for men and women under the law. Officially, women are entitled to equivalent positions with men in policymaking institutions like boardrooms, legislature and managerial committees. In recent times, some attempts to re-emphasize and acknowledge the significant role of gender parity in national development have been made. These include the creation of the Women Affairs Ministries at both National and state basis and the inclusion of more women in past and current administrations, however quite a lot still needs to be 
done. Given their obvious prospects, women inclusion in the development process is a primary means of vibrant socioeconomic change.

\section{Recommendations}

To enhance gender parity, male-centred structures must be diminished to guarantee equal access. Egalitarian standards must constitute the foundation of early socialization of children to break traditional attitudes and stereotypes. Females must contend alongside males for posts to manipulate civic rules regulations and laws in their support knowing that, control cannot be prearranged for them just like that. Funding agencies must encourage more collaborative research on diverse aspects of gender disparities to attain sincere egalitarianism between males and females in the rule procedure. The few women already in high positions must demonstrate positive role modelling and mentor younger ones. Research and training programmes and efforts in the area of women studies should be intensified while gender training and orientation must be promoted.

\section{Conclusion}

This paper presents a broad situational analysis of gender parity in Nigeria and considers development in significant aspects like: employment, education, earnings, poverty and political representation. It ascertains that females experience methodical drawbacks plus iniquitousness specifically more grievous for individuals in the more deprived states and zones of the nation. The country's 80.2 million females boast considerably poorer lifetime prospects compared not only to males but even other females in similar nations. Nevertheless women constitute Nigeria's concealed resource and empowering women and girls has the prospect of boosting national productivity now in addition to encouraging sustainable growth, peace and development. It consequently advocates plans and strategies aimed at improving the lifestyles of the females. Disparity hurts social unity and could intensify conflict, particularly when particular societal clusters are distinguished as being barred from chances. Conflict negatively affects women and girls, diminishing their freedom of movement and hindering their contribution to social, economic and political life.

\section{Refernces}

Badmus, Isiaka Alani (2015) "Political Parties and Women\&\#39;s Political Leadership in Nigeria: The Case of the PDP, the ANPP, and the AD", Ufahamu: A Journal of African Studies/00415715, 20060301

British Council Nigeria (2012) Gender in Nigeria Report www.britishcouncil.org.ng

British Council Nigeria (2012) Gender Equality Report www.britishcouncil.org.ng

British Council Nigeria (2013) Gender Impact Report www.britishcouncil.org.ng

British Council Nigeria (2014) Gender Impact Report www.britishcouncil.org

Caprioli, M. (2005) Primed for Violence: The Role of Gender Inequality in Predicting Internal Conflict. International Studies Quarterly 49, 161-178.

Corbridge and Pilbeam (2010), People Resourcing and Talent Planning: HRM in Practice.researchportal.port.ac.uk

Cox, T. O'Neill, P and Quinn, R (2001) Effects of Labour Market Institutions and Establishment Characteristics on Gender Wage Inequality in Africa: Evidence from Industry Survey Data in Nigeria. International Journal of Sociology and Social Policy. Vol. 18, No. 9/10, 309-325.

Daudia, R.O.S. (2007) Female Education and Nigeria's Development Strategies: Lots of Talk, Little Action. Indian Journal of Gender Studies, Vol. 14, No. 3, 461-479.

Fapohunda, Tinuke M. (2012) "Gender and Development: Challenges to Women Involvement in Nigeria's Development." International Journal of Academic Research in Business and Social SciencesVol. 2 Issue. 6. June 2012. Human Resource Management Academic Research Society, USA.

Fapohunda, Tinuke M. (2013) "The Gender Pay Gap in Nigeria: Causes and Remedies" Mediterranean Journal of Social Sciences Vol. 4, No.2, 2013. Mediterranean Center of Social and Educational Research University of Rome, Italy.

Halkias, et al. (2011) Challenges facing women entrepreneurs in Nigeria. Management Research Review, 34(2), 221-235.

Hunt, F. (2008) Dropping out from school: a cross-country review of literature. CREATE Pathways to Access, Research Monograph No. 16, May 2008.

Iheduru, N.G. (2006) Women Entrepreneurship and Development: The Gendering of Microfinance in Nigeria. Paper presented at the 8th International Interdisciplinary Congress on Women, 21-26 July 2002 at Makerere University, Kampala.

International Labour Organization (2006) World Employment. www.lo.org/public/english bureau/inf/pkit

Loden, M., and Rosener, J.B. (2009), Workforce America! Managing Employee Diversity as a Vital Resource, Burr Ridge, IL: Irwin.

Mahdi, S. (2011) Position Paper on the Political Context for Development and Gender Equality in Nigeria. 
Makower, Thomas \& Schuler, (1995) "Managing diversity in the workplace" Business and society Review

McKenna, L. (2009) Moving beyond adversarial relationships, Canadian Business Review , 22 (2), Summer, pp. 25-7.

Melander, E. (2005) Gender Equality and Intrastate Armed Conflict. International Studies Quarterly, 49, 695-714.

Morrison, A., Raju, D. and Sinha, N. (2007) Gender Equality, Poverty and Economic Growth. Policy Research Working Paper. The World Bank, Washington.

Nolte, I., Danjibo, N., and Oladeji, A. (2010) Religion, Politics and Governance in Nigeria. Religions and Development Research Programme, Working Paper 39. University of Birmingham.

Olojede Iyabo (2009), "Women: The Neglected Force in Public Administration" $2^{\text {nd }}$ Inaugural Lecture of the Faculty of Management Sciences LASU Ojo.

Ugwulebo, B.A. (2011) Female Gender in Professional Education. Marketing and Management of Professional Survey Education.

UNDP (2012), National Human Development Report 2012 www.ng.undp.org

UNDP (2014) National Human Development Report 2014. www.ng.undp.org

UNESCO (2014) World Data on Education. 2011-2015.

United Nations Economic Commission for Africa (UNECA) (2002) Africa Women's Report 2002.

World Bank. (2009) School Education in Nigeria: Preparing for Universal Basic Education. Africa Region Human Development Series. No 53. The World Bank, Washington. 